\title{
Latex sensitization in patients with myelomeningocele undergoing urological procedures: prevalence and associated factors
}

\author{
Iracy Silvia Corrêa Soares, MD • Clóvis Eduardo Santos Galvão, MD, PhD • \\ Maria José Carvalho Carmona, MD, PhD • Matheus Facchini Vane, MD • \\ Joaquim Edson Vieira, MD, PhD
}

Received: 13 November 2015/Revised: 7 March 2016/ Accepted: 24 March 2016/Published online: 31 March 2016

(C) Canadian Anesthesiologists' Society 2016

\section{To the Editor,}

Natural latex is a compound retrieved from the rubber tree (Hevea brasiliensis) that is widely used in medical materials. Since 1980, the increasing incidence of latex allergy has paralleled the widespread use of those materials. Its prevalence is currently decreasing, however, because of the improved quality of the latex and allergy prevention. ${ }^{1}$ Patients with myelomeningocele (MMC), a malformation of the neural tube, may exhibit a widely ranging prevalence of sensitization to latex.

We studied the prevalence of latex sensitization in patients with MMC undergoing repeated urological surgery. We interviewed MMC patients of both sexes, ten years of age or older, who had undergone at least one surgery and who had had a venous blood sample collected. ${ }^{2}$ All of the blood samples were analyzed using the ImmunoCAP ${ }^{\circledR} 100$ Phadia method (Phadia AB, Uppsala, Sweden) to detect specific immunoglobulin (IgE) with values $\geq 0.10 \mathrm{KUA} \cdot \mathrm{L}^{-1}$ (kilo allergen-specific antibodies per litre). The higher the value, the greater was the IgE concentration in the sample. Values $>0.7 \mathrm{KUA} \cdot \mathrm{L}^{-1}$ were considered markers of sensitization. ${ }^{3}$ The project was approved by the Ethics Committee for Research Projects of the Faculty of Medicine, University of São Paulo (Protocol 0767/08, 20 March 2013).

I. S. C. Soares, MD - C. E. S. Galvão, MD, PhD .

M. F. Vane, MD - J. E. Vieira, MD, PhD ( $₫)$

Clinics Hospital of University of São Paulo Medical School, University of São Paulo Medical School, São Paulo, SP, Brazil e-mail: joaquimev@usp.br

M. J. C. Carmona, MD, PhD - M. F. Vane, MD .

J. E. Vieira, MD, $\mathrm{PhD}$

Department of Surgery, University of São Paulo Medical School,

São Paulo, SP, Brazil
Table Symptoms of latex allergy and sensitization in patients with myelomeningocele

\begin{tabular}{|c|c|c|}
\hline & $\begin{array}{l}\text { Non-sensitized } \\
(n=29)\end{array}$ & $\begin{array}{l}\text { Sensitized } \\
(n=22)\end{array}$ \\
\hline Age $(y r) *$ & 19 [11-35] & $19.5[10-40]$ \\
\hline \multicolumn{3}{|l|}{$\operatorname{Sex} * *$} \\
\hline Male & $16(55 \%)$ & $10(45 \%)$ \\
\hline Previous surgeries* & $6[2-30]$ & $10[4-26]$ \\
\hline History of anaphylaxis & $4(14 \%)$ & $9(41 \%)$ \\
\hline \multicolumn{3}{|l|}{ ASA questionnaire $* *$} \\
\hline Asthma & $3(10 \%)$ & $6(27 \%)$ \\
\hline Eczema & $5(17 \%)$ & $6(27 \%)$ \\
\hline Autoimmune diseases & $2(7 \%)$ & - \\
\hline On-the-job exposure to latex & $2(7 \%)$ & $3(14 \%)$ \\
\hline Catheterized to urinate & $24(83 \%)$ & $22(100 \%)$ \\
\hline History of previous allergies & $8(28 \%)$ & $14(64 \%)$ \\
\hline History of food allergies & $4(14 \%)$ & $5(23 \%)$ \\
\hline Bananas $^{\#}$ & $3(10 \%)$ & $3(14 \%)$ \\
\hline History of latex allergy & $9(31 \%)$ & $17(77 \%)$ \\
\hline \multicolumn{3}{|l|}{ Self-reported symptoms } \\
\hline Hives & $9(31 \%)$ & $12(54 \%)$ \\
\hline Itching & $8(28 \%)$ & $9(41 \%)$ \\
\hline Wheezing & $2(7 \%)$ & $7(32 \%)$ \\
\hline Difficulty breathing & $4(14 \%)$ & $9(41 \%)$ \\
\hline Watery eyes & $4(14 \%)$ & $10(46 \%)$ \\
\hline Edema & $7(24 \%)$ & $15(68 \%)$ \\
\hline Non-characterized & $8(28 \%)$ & $15(68 \%)$ \\
\hline Blowing up balloons & $8(28 \%)$ & $15(68 \%)$ \\
\hline Dental/medical examinations & $1(3 \%)$ & $2(9 \%)$ \\
\hline Wearing rubber gloves & $7(24 \%)$ & $11(50 \%)$ \\
\hline
\end{tabular}

* Median [interquartile range]; ** Number $(\%)$; ${ }^{\#}$ No history of allergies to kiwi fruit, avocados and chestnuts. ASA = American Society of Anesthesiologists 
Of 212 patients with MMC, 68 had undergone at least one surgical procedure. In all, 51 patients agreed to participate, and 22 (43\%) of them had K82 antibody levels $\geq 0.7 \mathrm{KUA} \cdot \mathrm{L}^{-1}$. They were thus considered to be latexsensitive. Although the age and sex of patients with and without K82 antibodies were similar, those considered sensitized reported more surgeries and were more likely to self-report symptoms of latex sensitization (Table).

Although a history of allergy may not be entirely reliable, these data show that some symptoms could be used to help the clinician identify latex sensitization in an at-risk population. It is interesting to note that, although 26 patients $(51 \%)$ claimed a history of latex allergy, only 17 tested positively for sensitization, and nine were negative.

The specificity of the relation between spina bifida and the repeated exposure to surgery probably refers to a combination of genetic and environmental factors. Some data indicate that potent allergens (e.g., latex) in high-risk groups (e.g., those with spina bifida) can induce sensitization, and, conversely, avoidance can reverse it. ${ }^{4}$ Therefore, the early recognition of sensitized patients, even when already in a risk group, may benefit from a focused interview. Indeed, in one study, a brief questionnaire better identified suspected latex sensitivity than a standard verbal inquiry (e.g., "Are you allergic to medications or latex?"). The results presented herein suggest that key symptoms may identify those sensitized to latex even when already in an at-risk condition.
Funding The Brazilian agency FAPESP, Fundação de Amparo à Pesquisa do Estado de São Paulo provided funds to purchase the reagents used in this investigation (Process 2013/18906-6). FAPESP: Rua Pio XI, 1500, São Paulo/SP - Brazil, CEP 05468-901; Website: http://www.fapesp.br/

Competing interests None declared.

Editorial responsibility This submission was handled by Dr. Gregory L. Bryson, Deputy Editor-in-Chief, Canadian Journal of Anesthesia.

\section{References}

1. Blaabjerg MS, Andersen KE, Bindslev-Jensen C, Mortz CG. Decrease in the rate of sensitization and clinical allergy to natural rubber latex. Contact Dermatitis 2015; 73: 21-8.

2. Holzman RS, Brown RH, Hamid R, et al. Natural rubber latex allergy: considerations for anesthesiologists. American Society of Anesthesiologists. Availble from URL: http://www.ibrarian.net/ navon/paper/American_Society_of_Anesthesiologists.pdf?paperid= 2785774 (accessed March 2016).

3. Ausili E, Tabacco F, Focarelli B, Nucera E, Patriarca G, Rendeli $C$. Prevalence of latex allergy in spina bifida: genetic and environmental risk factors. Eur Rev Med Pharmacol Sci 2007; 11: 149-53.

4. Niggemann B. IgE-mediated latex allergy-an exciting and instructive piece of allergy history. Pediatr Allergy Immunol 2010; 21: 997-1001.

5. Peer L, Brezis $M L$, Shalit $M$, et al. Evaluation of a prospectively administered written questionnaire to reduce the incidence of suspected latex anaphylaxis during elective cesarean delivery. Int J Obstet Anesth 2014; 23: 335-40. 